Author accepted manuscript, postprint

Kangas, H-L., Lyytimäki, J., Saarela, S-R., \& Primmer, E. (2018). Burning roots: Stakeholder arguments and media representations on the sustainability of tree stump extraction in

Finland. Biomass and bioenergy, 118, 65-73. https://doi.org/10.1016/j.biombioe.2018.08.006

Hanna-Liisa Kangas, Jari Lyytimäki, Sanna-Riikka Saarela, \& Eeva Primmer

\title{
Burning roots: Stakeholder arguments and media representations on the sustainability of tree stump extraction in Finland.
}

\section{Abstract}

The sustainable use of forest resources is an intensively debated topic, raising environmental, socio-cultural and economic concerns. The debate culminates around forest bioenergy. The bioenergy debate has been characterized by a strong polarisation between different perspectives on environmental impacts. In particular, the claims about carbon sequestration have been contrasted with other ecological impacts. This article focuses on the debate over the use of tree stumps as a relatively novel source of forest bioenergy. To shed light on the constellation of the different arguments and actors in the debate on the sustainability of forest bioenergy, we conducted an empirical qualitative analysis of Finnish argumentation on tree stump removal, using media and interview data and relating the emerging sustainability arguments to the dimensions debated in the EU biofuel sustainability policy. The analysis shows the variation of views across Finnish expert stakeholders and the fora where the arguments are made. Climate impacts dominate the media discussion, while other sustainability dimensions are covered in expert discussion. Our findings have implications for the interpretation and use of scientific arguments in energy debates, in particular regarding environmental sustainability.

\section{Keywords}

Bioenergy; Environmental impacts; Expert knowledge; Media debate; Sustainability criteria; Tree stumps

\section{Highlights}

Bioenergy is an important part of renewable energy portfolio.

Sustainability of forest-based bioenergy is debated.

The arguments in the media and among experts adhere to different framings.

Climate impacts stand out in the media discussion of stump energy use.

The results show that science contributes to public discussion and concern. 


\section{Introduction}

The sustainability of the use of forest resources has been debated in science and policy for decades, but the aim to substitute fossil fuels with renewable energy has intensified this debate significantly, raising further environmental, socio-cultural and economic arguments [1,2]. Forest bioenergy is currently the largest source of renewable energy in Europe [3,4], and its increasing use has been justified by environmental and sustainability arguments. These arguments have emphasised in particular the renew able character of the energy source and possibilities to reduce carbon emissions to the atmosphere [[5], [6], [7]]. On the other hand, concerns have been voiced about biodiversity loss and other harmful environmental impacts of forestry [8]. Consequently, the policy debate over forest-based bioenergy has been characterized by a relatively strong polarisation between different perspectives on sustainability impacts. The polarisation may hide the different dimensions of sustainability and the nuances that ste $m$ from the specific ecological and socio-cultural contexts [1,9].

Forest bioenergy in European countries usually originates from stems, tree tops and branches from logging residues from final and intermediate harvests [10]. In addition to the above-ground tree biomass, also tree stumps and roots can be used as an energy source. Stump extraction and energy use have been rather modest in Europe, with only Finland, Sweden and United Kingdom having actively taken up the practice $[11,12]$. Because of increasing demand for renewable energy, a shift towards increasing utilisation of stumps has been anticipated $[13,14]$.

Although tree stumps can be considered yet another renewable woody biomass resource in the forest, recent studies show that stump removal may cause distinctive environmental impacts and reduce ecosystem services [[15], [16], [17], [18]]. Removal of harvest residues has been criticized because it reduces water and nutrient retention $[19,20]$ and coarse dead wood $[18,21]$ that constitutes a habitat for coarse woody dependent species $[22,23]$. The harvesting of logging residue and stump may also decrease spruce productivity [24]. In essence, the provision of renewable energy faces trade-offs with carbon, nutrient and hydrological regulation and biodiversity conservation as well as recreation aesthetic ecosystem services [17,[25], [26], [27]].

Due to the relatively recent uptake of large-scale stump removing practice, there are limited comprehensive long-term data or thorough life-cycle assessments $[16,28]$, which results in uncertainty about the impacts of the practice $[14,29]$. The climate benefits of forest bioenergy have been internationally debated [e.g. [30], [31]]. Scientific studies have resulted in different conclusions on the magnitude and timing of possible climate benefits of using stumps for bioenergy [6,16,[32], [33], [34]]. Selective use of such scientific results can effectively fuel the arguments serving the interests of opposing parties in public and policy debates.

The policy discussion around stump removals has gained media attention in Finland, portraying the above mentioned various science-based environmental arguments. Yet, as is the tendency in media coverage [35], the reporting picks the catchy arguments, such as the newspaper headline: "It turns out that burning stumps is a sin" (Helsingin Sanomat, 3.12.2010). The bioenergy media discussion has been mainly centred on climate change impacts and related research findings, which has also been observed in other energy debates in the media $[7,36,37]$. However, science is not the only source of information for the media reporting on sustainability issues. Policymakers, business representatives and other elite stakeholders hold a key position, as news sources and some news reports seek to balance the elite views and scientific reasoning with timely grass-root level experiences and views of lay people. For example, the news reporting of forest fires in Indonesia has been shown to rely more on non-scientist views [38]. In line with the observation of the polarisation and reliance on science in the Finnish media, public views on stump harvesting have also been shown to be polarised, particularly among people with much knowledge on the matter [39].

Even when different forest-related stakeholders have access to the same scientific information, their perceptions might differ based on their interests, values and emotional bonds [[40], [41], [42]]. Lindahl and Westholm [41] argue that stakeholders conceptualise new issues in ways that are compatible with their deeply rooted forest-related conceptual frames and action strategies. Alternatively, new issues could open possibilities for reframing old stakeholder positions. Stakeholder groups with differing interests play an important role in forest policy and management $[43,44]$, so understanding stakeholder views and framing 
in energy wood policy design is crucial [40]. Indeed, building on their understanding of public views, Rahman et al. [39] call for a study on experts' perceptions and attitudes related to stump harvesting.

In this paper, we shed empirical light on the sustainability debate around bioenergy use by analysing expert stakeholder arguments on stump extraction in Finland. With our qualitative analysis, we seek to elucidate the role of sustainability knowledge claims made by different stakeholders and the prevalence of different arguments in different fora. We combine sets of media data and expert interviews to identify and compare the focus on sustainability concerns and different arguments expressed in the public discussion in (1) the media and (2) in the expert-level discussion that is less visible to the public.

Specifically, our research questions are: (1) How do stakeholders view the sustainability dimensions of stump removals in Finland? (2) What are the differences between (a) different stakeholders' arguments and (b) the fora where the arguments are made, i.e. media debate and expert argumentation? In the following, we first describe the policy setting of bioenergy and stump removal. Based on the results, we discuss the implications on the use of science and knowledge claims about environmental sustainability in energy debates.

\section{Stump extraction and bioenergy policies in Finland and the EU}

Fuelwood is the world's largest forest product type. In 2011, wood removals amounted to 3.0 billion m3 globally, of which $49 \%$ were for wood fuel [45]. Finland provides a particularly interesting case to study forest bioenergy and tree stump removal. In the EU climate and energy burden sharing, Finland's share of renewable energy must be at least $38 \%$ of the final energy consumption by 2020 . Finland has committed to meeting about $80 \%$ of the target with bioenergy, which comprises mainly forest bioenergy $[46,47]$.

Furthermore, there are other recent policy initiatives that directly or indirectly target (or contradict) forest bioenergy. For example, one of the five strategic priorities in the current Finnish government program, 'Bioeconomy and clean solutions', aims at increasing the uses of renewable resources for the production of bio-based products, food, feed, energy and services [48]. At the same time, there is a strong plea for a circular economy that aims to maximize the circulation of products, components and materials, and minimize raw material consumption and waste [49].

In addition to general policy goals, Finland's forest-based bioenergy production and use are promoted through a range of policy instruments [26]. As for promoting stump use, the most relevant subsidy has been the feed-in premium for electricity production from renewable sources in combined heat and power (CHP) plants. These CHP plants usually mix different solid fuels (wood, peat or coal), and the policy is aimed at increasing the share of bioenergy in the mix [50]. Stumps bring impurities (e.g. stones and sand) with them, so their use requires appropriate technology and causes extra maintenance costs for the power plants.

As a result of Finland's bioenergy promoting policies [26,51], the use of forest-based biomass in energy production has increased rapidly in Finland (see Fig. 1). For stumps, the increase was even faster; their use in energy production multiplied by 240 times during the years 2000-2013 [52]. However, stump use decreased during 2014-2015. 
(a)

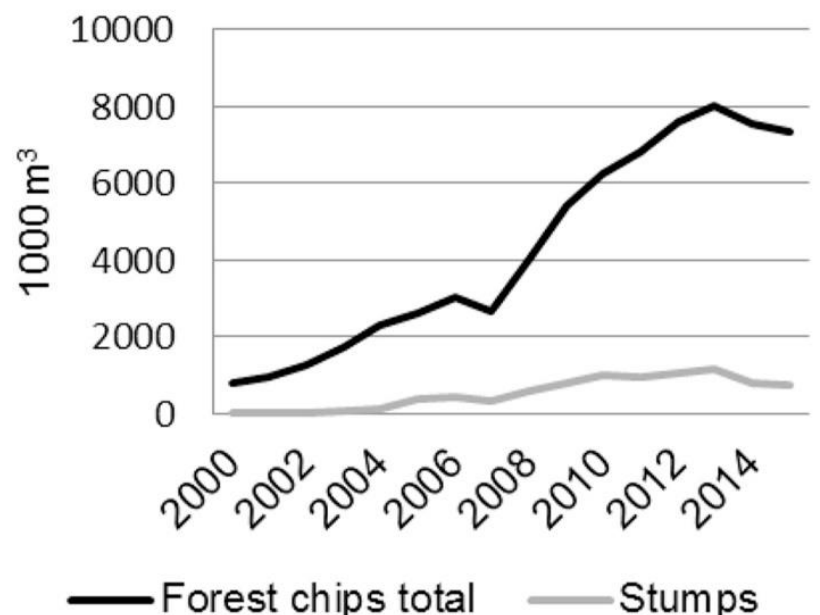

(b)

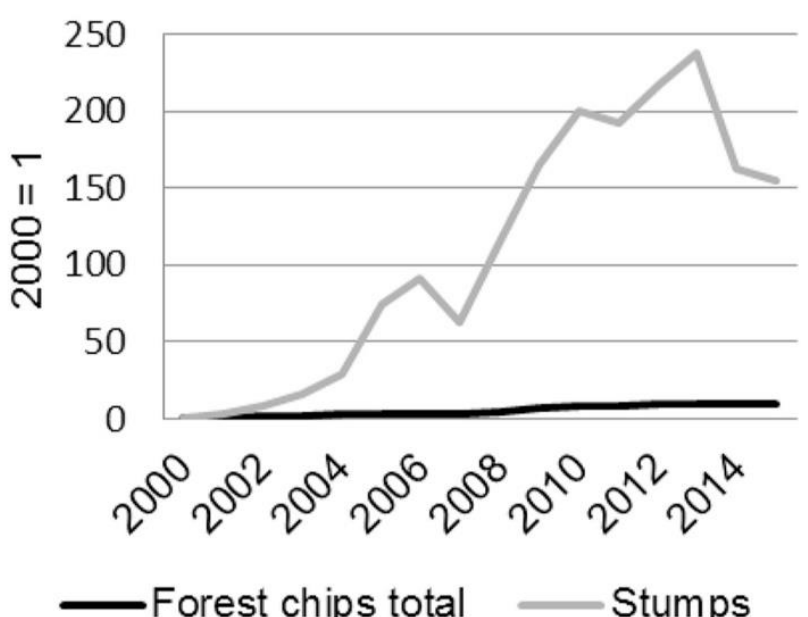

Fig. 1. Total forest chips' (comprising of small-sized trees, logging residues, stumps and large-size timber) and stumps' energy use in Finland 2000-2015 (a) in absolute numbers (1000 m3) and (b) normalized so that the year $2000=1$ $[52,53]$.

Finnish silviculture is primarily governed by the Forest Act (1997, amended in 2013). The Act is operationalised in practice through nationally applied voluntary forest management guidelines, which guide tree stump extraction as well [54]. Although the guidelines align the best sustainable practice for silvicultural operations in general, they do not set limits for large-scale tree stump extraction. The main forest certification scheme in Finland, namely the Programme for the Endorsement of Forest Certification (PEFC), and also the Forest Stewardship Council (FSC) allow stump extraction $[55,56]$. The stump extraction rules in these certification schemes differ from similar schemes in neighbouring contexts, as for example the Swedish FSC certificate strongly limits stump extraction [57].

To capture the environmental and sustainability concerns in a comprehensive manner at the EU level, the introduction of specific sustainability criteria or standards has been a key effort, drawing on scientific evidence and political iteration. The EU has set sustainability standards for biofuels and bioliquids as a part of its 2020 climate and energy package. However, EU-wide mandatory sustainability standards do not exist for solid biomass use [58]. Instead, the European Commission (EC) has proposed that EU Member States would set national sustainability schemes [59]. Finland, Sweden and the UK have established voluntary tree stump harvesting guidelines to support sustainable practices [[60], [61], [62]]. The EC is curren tly in the process of preparing a bioenergy sustainability policy for the 2030 climate and energy package. The preparatory process has included a consultation with citizens and stakeholders, addressing a range of possible sustainability risks of bioenergy use [63], including:

- Climate change impacts: lifecycle greenhouse gas emissions from bioenergy production and use, impacts on the carbon stock of forests and other ecosystems, and indirect land use change impacts.

- Other environmental impacts: biodiversity, soil and water, and emissions to the air.

- Competition for the use of biomass between different sectors: energy, industrial uses, food.

\section{Methods and data}

With the aim to analyse sustainability arguments made by different expert stakeholders in different fora, we conducted a qualitative analysis combining two different datasets. This approach provides rich material needed to understand the complex phenomenon to which divergent value positions and contested knowledge claims can be attached $[64,65]$. The approach allows in-depth examination of the specific social, cultural, technical and ecological dimensions of energy policy $[9,17,66,67]$. Our analysis of argume nts on tree stump use for bioenergy makes use of two data sources: (1) expert stakeholder interviews and (2) news items in the media (Table 1). The analysis is designed to identify the dimensions represented in the 
data by analysing arguments and to identify their key characteristics and connect them with the stakeholders making the arguments. This mixed method combines qualitative interpretation and explanation $[65,68]$. The data were analysed following a qualitative content analysis approach [69], whilst interpreting the publicly presented written media contents and spoken (transcribed) arguments as presented in interviews.

Table 1. Materials of the study.

\begin{tabular}{|l|l|l|}
\hline & \multicolumn{1}{|c|}{ Interviews } & \multicolumn{1}{|c|}{ Media analysis } \\
\hline $\begin{array}{l}\text { Number of } \\
\text { units }\end{array}$ & $\begin{array}{l}\text { 17 semi-structured theme interviews, } \\
\text { complementary questions by e-mail }\end{array}$ & 56 news stories \\
\hline $\begin{array}{l}\text { Temporal } \\
\text { coverage }\end{array}$ & $\begin{array}{l}\text { Interviews performed during March- } \\
\text { September 2016 }\end{array}$ & $\begin{array}{l}\text { News coverage from August 2010 to May } \\
2016\end{array}$ \\
\hline $\begin{array}{l}\text { Sectors } \\
\text { covered }\end{array}$ & $\begin{array}{l}\text { 2 environmental NGOs, 1 energy industries, 1 } \\
\text { forest industries, 8 researchers, 3 government } \\
\text { officials, 1 forest owners and 1 advisory } \\
\text { organisation }\end{array}$ & $\begin{array}{l}10 \text { newspapers, 4 political party } \\
\text { publications, 4 professional magazines } \\
\text { and websites, 2 tabloids, 2 news } \\
\text { websites and 2 magazines }\end{array}$ \\
\hline
\end{tabular}

The identified arguments were grouped under five categories representing different dimensions of sustainability: (1) climate change, (2) other environmental impacts, (3) biomass use competition, (4) landscape and recreation, and (5) economic impacts. This categorization captures policy-driven sustainability criteria of the European Commission [59] and acknowledges the range of potential ecosystem service impacts and trade-offs [17]. The actors presenting their views and arguments made for and against stump removals were identified and divided into 7 representative groups: (1) environmental nongovernmental organizations (NGOs), (2) energy industries, (3) forest industries, (4) researchers, (5) government officials, (6) forest owners, and (7) advisory organisation.

Making use of the stakeholder groups and sustainability dimensions, the arguments of the two datasets were tabulated into matrices of arguments. For example, all environmental NGOs' representatives' arguments on climate change impacts on stump removals in the media data were collected into one cell in the matrix. To evaluate the differences between different stakeholders' arguments, we then rated the arguments on a scale ranging from very negative to very positive as regards stump extraction (Table 2). The ratings were given to each cell in the matrix. This type of analysis is always subjective $[65,69]$. We minimised the subjectivity by: (a) conducting ratings by three independent researchers, and (b) reassessing all potentially unclear cases by all researchers until a consensus was reached.

Table 2. Qualitative rating of arguments for the sustainability impacts.

\begin{tabular}{|l|l|}
\hline Rating & \multicolumn{1}{|c|}{ Measure for rating } \\
\hline-- & $\begin{array}{l}\text { Only multiple negative arguments mentioned or the argument that stumps should not be } \\
\text { extracted for this reason. }\end{array}$ \\
\hline- & Mainly negative arguments. \\
\hline 0 & Neutral arguments. \\
\hline$+/-$ & Evenly spread negative and positive arguments. \\
\hline+ & Mainly positive arguments. \\
\hline++ & Only multiple positive arguments mentioned. \\
\hline
\end{tabular}


The material included the transcripts of the interviews and the titles, texts and potential picture captions of the news items. The 17 semi-structured interviews were carried out in March-September 2016. Interviews of researchers were complemented with brief additional questions through email. The interviewees were selected to represent expertise and interests relevant for stump use, including environmental NGOs, energy industries, forest industries, researchers, government officials, forest owners and advisory organisations. Energy and forest industries were represented through their advocacy organisations in the interviews. In the media data, the industries were represented mostly through spokespersons of big corporations. Forest owners were represented through their advocacy organisation, both in the interviews and in the media data.

The interview themes included environmental, social and economic impacts of forest bioenergy production, information uncertainties and national debate on forest bioenergy policy and production. In addition, a specific question on the interviewees' personal views about stump extraction was asked. The face-to-face interviews lasted 45-90 min and were recorded and transcribed. The email responses varied between 42 and 245 words in length.

The media material included popular and professional newspapers and magazines. The basis of the media material was a bioenergy news sample collected by the Finnish Environment Institute. To ensure that all relevant media material was included in the analysis, the sample was complemented with an extensive online Google online search in August 2016, using keywords "stump energy" (kanto energia in Finnish), "stump use" (kantojen käyttö), "stump burning" (kantojen poltto) and "stump extraction" (kannonnosto), which were based on iterative testing of various search strings. Altogether, 109 different media outlets were included, resulting in a comprehensive set of key media arenas of public debate related to energy issues in Finland. Letters to the Editor and other opinion pieces were excluded from the sample. Also, news items that did not handle stumps directly were left out, even if they covered forest bioenergy. The final media data consisted of 56 news items.

Most of the news items (28) were published by newspapers, the main ones being Helsingin Sanomat (HS, 8 items) and Maaseudun Tulevaisuus (MT, 7 items). HS is the most widely read Finnish newspaper, while MT is the leading national newspaper focusing on rural issues. Other publication channels were political party publications ( 8 items), professional magazines and their websites ( 7 items), popular magazines ( 7 items), news websites ( 4 items) and tabloids ( 2 items). Photographs or graphics of the news items we re not studied. The Finnish Environment Institute published 3 press releases (9/2010, 2/2011 and 5/2013) about the new research results on the climate impact of stump energy use. These press releases were not studied as media material, but they were important background information for the news items.

\section{Results}

\subsection{Overall characteristics of the debate}

Generally observing the intensity of the public debate based on the publication dates, we found that it varied considerably (Fig. 2). In the media, out of the 56 news items, 29 handled stumps together with other bioenergy sources. Despite its specific character, stump use for bioenergy was the sole focus of 24 news items. The media debate typically circled around topical issues of energy policy and focused on a limited set of impacts. The reported energy policy issues were mostly focused on the national implementation of EU energy policy, including the 2020 climate and energy package and sustainability criteria of bioenergy. 


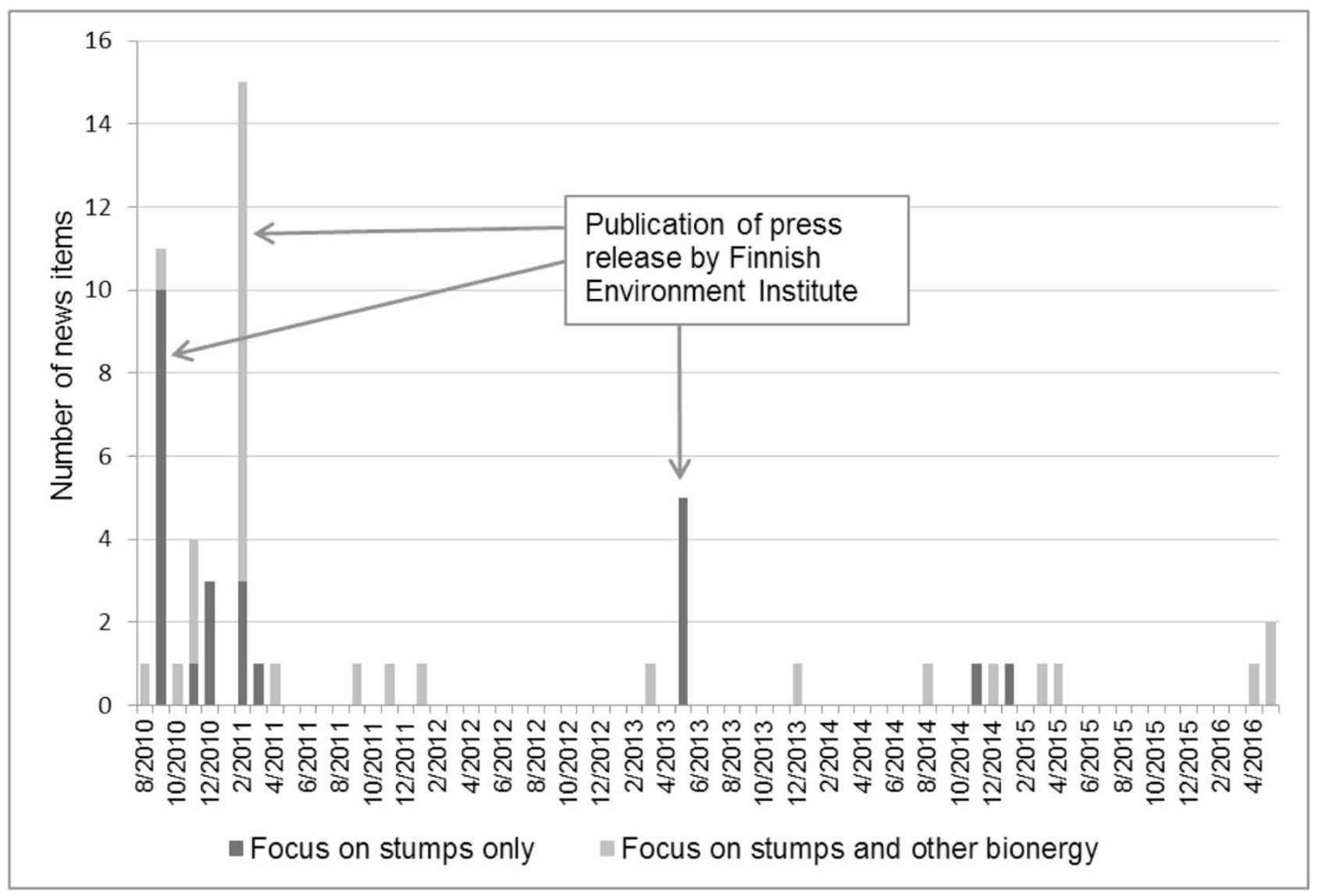

Fig. 2. Number and focus of news items per month 8/2010-5/2016.

Of the analysed sustainability dimensions, climate change impacts were the most frequently addressed dimension in the media. Almost all news items covered climate change impacts of the energy use of stumps (Table 3). Landscape and recreational impacts of stump use were covered only in a few news items. When looking at all sustainability dimensions, the overall positions of stump energy use sustainability between the interviews and the news items did not differ much, yet the arguments in the news items were generally slightly more critical towards stump utilisation than the arguments made in the interviews. The arguments made in the interviews displayed markedly more nuance and variation than the media.

Table 3. Number and percentage of news items $(n=56)$ mentioning different sustainability dimensions.

\begin{tabular}{|l|l|l|l|l|l|}
\hline \multicolumn{1}{|c|}{$\begin{array}{c}\text { Sustainability } \\
\text { dimension }\end{array}$} & $\begin{array}{c}\text { Climate } \\
\text { change }\end{array}$ & $\begin{array}{c}\text { Other } \\
\text { environmental } \\
\text { impacts }\end{array}$ & $\begin{array}{c}\text { Biomass } \\
\text { competition }\end{array}$ & $\begin{array}{c}\text { Landscape and } \\
\text { recreation }\end{array}$ & $\begin{array}{c}\text { Economic } \\
\text { impacts }\end{array}$ \\
\hline $\begin{array}{l}\text { Number of news } \\
\text { items mentioning }\end{array}$ & 51 & 11 & 8 & 3 & 17 \\
\hline $\begin{array}{l}\text { Percentage of news } \\
\text { items mentioning }\end{array}$ & $91 \%$ & $20 \%$ & $14 \%$ & $5 \%$ & $30 \%$ \\
\hline
\end{tabular}

The interviews reflected the public debate at the time, but they addressed a broader set of impacts as compared to the media. The interviewees brought up especially non-climate environmental impacts, linking them with, e.g., stump removal standards of fore st certification schemes or voluntary forest management guidelines. The interviewees referred to research findings or their own expertise and experiences in stump use for energy. Lack of expertise on certain defined impacts and an overall need for further research was emphasised by several interviewees. Also the media items included some references to lack of knowledge. 
The views presented by each analysed stakeholder group were typically coherent, but specific arguments revealed the complexity of the issue and the importance of temporal and spatial framings adopted in argumentation. However, there were some exceptions to the group-based views. The most distinct was the spread of the views of researchers on climate impacts. Although most researchers both in the interviews and the media made very negative arguments on the climate impacts of the energy use of stumps, notably there were also researchers taking the opposite position.

Research findings had a high visibility in the news media representations. Most media items were published close to the Finnish Environment Institute's press releases on bioenergy's negative climate impacts (see Fig. 2). Typically, the news items reported a new research result and complemented it with different stakeholder views. In the news items, the arguments were often simplified. In the interviews, the stakeholders considered multiple impacts and highlighted various uncertainties.

The decrease in the recent years' stump energy use (Fig. 1) was acknowledged in the latest news items in 2014-2016. The reasons given by stakeholders for this drop varied, from the additional costs of stump cleaning before burning to the low price of coal and the harmful environmental impacts. For example:

"The outlook seems quite pessimistic right now be cause of the purity problems of stumps, image problems of stump extraction and the carbon debt question." [researcher, media].

\subsection{Arguments by stakeholdertypes}

Based on our classification and rating of the arguments, we can see that in both datasets, the most critical arguments on stump utilisation were given by environmental NGOs, followed by researchers, forest owners and energy industries (Table 4). Forest industries, government officials and advisory organisations voiced the most positive arguments on stump use sustainability.

According to how the arguments addressed the five sustainability dimensions, the stakeholders appeared most critical of the impacts on landscape and recreation and other environmental impacts. In general, stakeholders made mostly positive arguments about the impacts of stump utilisation on biomass competition and economy. The stakeholders' takes on the climate impacts of using stumps for energy varied from quite negative to very positive.

Table 4. Argument ratings from the interview and media data, by each stakeholder type on different sustainability dimensions of stump energy use. An empty cell refers to a case where the material does not include arguments.

\begin{tabular}{|c|c|c|c|}
\hline Stakeholder group & Sustainability dimension & Interviews & News items \\
\hline \multirow[t]{5}{*}{ Environmental NGOs } & Climate change & - & - \\
\hline & Other environmental impacts & -- & - \\
\hline & Competition & - & \\
\hline & Landscape & - & \\
\hline & Economy & + & \\
\hline \multirow[t]{5}{*}{ Energy industries } & Climate change & ++ & - \\
\hline & Other environmental impacts & 0 & 0 \\
\hline & Competition & & 0 \\
\hline & Landscape & - & \\
\hline & Economy & + & $+/-$ \\
\hline \multirow[t]{2}{*}{ Forest industries } & Climate impacts & ++ & + \\
\hline & Other environmental impacts & - & 0 \\
\hline
\end{tabular}




\begin{tabular}{|c|c|c|c|}
\hline Stakeholder group & Sustainability dimension & Interviews & News items \\
\hline & Competition & + & 0 \\
\hline & Landscape & - & \\
\hline & Economy & ++ & - \\
\hline \multirow[t]{5}{*}{ Researchers } & Climate impacts & - & - \\
\hline & Other environmental impacts & - & - \\
\hline & Competition & - & \\
\hline & Landscape & $+/-$ & \\
\hline & Economy & $+/-$ & $+/-$ \\
\hline \multirow[t]{5}{*}{ Government officials } & Climate impacts & $+/-$ & + \\
\hline & Other environmental impacts & -- & \\
\hline & Competition & + & + \\
\hline & Landscape & -- & \\
\hline & Economy & + & \\
\hline \multirow[t]{5}{*}{ Forest owners } & Climate impacts & + & + \\
\hline & Other environmental impacts & -- & \\
\hline & Competition & & \\
\hline & Landscape & - & - \\
\hline & Economy & + & - \\
\hline \multirow[t]{5}{*}{ Advisory organisations } & Climate impacts & - & $+/-$ \\
\hline & Other environmental impacts & - & $+/-$ \\
\hline & Competition & $+/-$ & \\
\hline & Landscape & - & \\
\hline & Economy & + & \\
\hline
\end{tabular}

Note: See Table 2 for explanations of the rating scores.

\subsubsection{Climate impacts}

The rating of the different stakeholder arguments addressing climate impacts showed that the views on these impacts of using stumps for energy diverged among the stakeholder groups (Table 4). Environmental NGOs, researchers and advisory organisations viewed climate impacts mostly as negative, whereas forest industries and forest owners had mainly positive views.

The arguments asserting negative climate impacts were based on the long time it takes for stumps to decay naturally in the forests compared to other forest chip sources such as branches. The positive arguments often focused on the possibility of substituting fossil fuel use with stumps in energy production. The time span and area of consideration were mentioned as important factors. The shorter the time span the stakeholders were considering, the more negative was their position on the climate impacts. For example:

"When the use of forest bioenergy increases, in the short term the emissions can be higher than with competing fossil fuels, such as coal, oil or natural gas." [researcher, media] 
Also the scale of the argument influenced how it was framed. Some stakeholders justified their positive climate impact views to Finnish forests as a whole, such as:

"If forests grow more than they are cut, the view on carbon storage is different than when looking at one tree." [energy industry, interview]

The arguments that stakeholders presented on climate impacts were in general slightly more critical in the news items than the arguments in the interviews. Research results showing negative climate impacts were emphasised by stakeholders more in the media than in the interviews. This difference was especially strong among the arguments of the energy industries, which were even anticipating policy changes due to the recent research findings:

"The emissions factors can be changed in the future, at least for the slowly growing tree parts such as stumps and roundwood." [energy industry, media]

\subsubsection{Other environmental impacts}

Almost all stakeholders' arguments on environmental impacts of stump energy use were dominantly negative. Only energy industries had neutral arguments about environmental impacts. The environmental impact arguments were generally more negative in the interviews than in the news items. The stakeholders highlighted biodiversity loss and impacts on water and nutrient retention as key negative impacts. They also emphasised the limited knowledge of the long-term environmental impacts. For example:

"Because stump removal has been intensively practised for such a short time, we don't know yet its impacts on biodiversity. So let's rather have some patience before we start to increase it massively." [government official, interview]

The most critical stakeholder group environmental NGOs raised numerous environmental impacts in the interviews, whereas their arguments in the media focused on biodiversity:

"Stump use is unsustainable and damaging to biodiversity." [environmental NGO, media]

The more neutral arguments highlighted uncertainties and also the lack of research on the long-term ecosystem impacts. In addition, tree stump use was contrasted with other potentially more harmful forms of human activity causing stress for the environment:

"This world works obviously so that if we live here, human impacts are surely to be seen." [energy industry, interview]

\subsubsection{Biomass use competition}

Generally, the arguments on the impacts of stump utilisation on biomass competition were neutral. The environmental NGOs and researchers made the most negative arguments on biomass competition issues, while government officials' arguments were mostly positive. In general, the stakeholders' take was slightly more critical in the interviews than in the media.

The negative arguments revealed the rationale that if stumps were burned, there would be less biomass available for other uses. This could in turn jeopardise the goals of the so-called bioeconomy, which had been adopted as a key policy objective in Finland. This line of argumentation emphasised the future use of forest resources:

"If all the bioproduct and bioenergy plans are carried out, it will be difficult to have enough wood for everything." [government official, interview]

However, the arguments supporting the energy use of stumps emphasised the difficulty in using them for any purposes other than electricity and heat production. Some stakeholders even argued that stump use would decrease the demand for other bioenergy sources:

"If [stumps] are left in the forest, it creates a pressure to burn more roundwood." [government official, interview]

The neutral arguments centred around the technical difficulties to replace other wood uses with stumps: 
"Stumps are not used at all in pulp production, and there are still challenges also in the fuel use of stumps." [forest industries, media]

\subsubsection{Landscape and recreation}

Most arguments on the impacts of stump energy use on landscape and recreation were negative and reliant on stakeholders' practical experience. Researchers had a descriptive approach referring to survey findings. None of the stakeholder groups had a positive view on the impacts on landscape and recreation. The positions were equally critical in the media and interviews. However, the media data were very thin regarding the landscape and recreation impacts.

The critical take was mostly argued with the aesthetic impacts of stump extractions and the difficulties to utilise the areas for recreation:

"Many just think that it looks ugly. The stump extraction area is undeniably quite awful looking." [government official, interview]

"Certainly stump extraction makes it more difficult to hike, at least for some time, because there are these holes." [advisory organisation, interview]

Stumps are left to dry on-site before they are utilised, which is very visible and can even be a surprise for the forest owners:

"The heaps of stumps dry there at the final felling site or next to the forest road for two years. No imagination can make them beautiful. So there is an experience of aesthetic harm." [forest owners, interview]

"The forest owners are rather surprised that the wood [stumps] can be stored there [on-site] easily for a year or two." [forest owners, media]

\subsubsection{Economic impacts}

Economic impacts were viewed both positively and negatively by researchers and forest owners, while all other stakeholder groups were mainly positive. The arguments of the stakeholders were notably more positive in the interviews than in the media. The biggest difference was with forest industries. They were very positive about the economic impacts in the interviews, but showed a slightly negative position in the news items:

"A lot of money is spent on energy and the bulk of that goes abroad when fossil fuels are imported. And overall, it [stump use] means income for forest owners. And it's a safety issue, energy self-sufficiency." [forest industries, interview]

"Nowadays there are only a very few power plants that accept them [stumps]." [forest industries, media]

The arguments varied from microeconomic impacts on the actors to large-scale macroeconomic impacts. At the macroeconomic scale, the positive impacts on employment were the most commonly mentioned. Also, the fact that stumps are a domestic energy production input was mentioned. Other positive impacts mentioned included the additional income opportunity for forest owners and positive local-level economic impacts. However, many stakeholders also raised concerns about the economic impacts of stump utilisation, especially in the news items. The most prevalent negative impact argument was the low fuel quality of stumps caused by their dirtiness, inducing difficulties and extra costs for energy production. One stakeholder summarised the positive and negative impacts in the following way:

"Obviously stumps are the kind of bioenergy source that is not very economical to extract, because it is dirty and it does not suit the energy production boilers very well. But it does bring work and income to the countryside." [government official, interview] 


\section{Discussion}

New natural resource use practices generate impacts and uncertainties, which are understood only partially and framed in differing ways by different actors in the society. The use of tree stumps for bioenergy in Finland is an interesting case of a new form of natural resource use because it has increased dramatically (yet starting to level) and because the climate change impacts of bioenergy have recently received heightened political and scientific attention. The novelty of the practice means that research based understanding is only starting to emerge and is be ing interpreted and framed by expert stakeholders in varying ways. These framings do not necessarily follow the argumentation lines of earlier debates on forest-based bioenergy [1]. However, our study shows that even with the new bioenergy source, the stakeholder argumentation lines are largely aligned with those identified in earlier national-level forest debates $[43,67,70]$.

Our analysis shows that a wide range of potential impacts are considered by experts representing different knowledge bases and interests when addressed confidentially. However, this diversity of arguments and considerations remains poorly addressed by the media. Instead, the arguments presented in the media centre around climate change. Our results also display some differences between the views stakeholders put forward in the interviews and the ones they present in the media. Energy industries and forest industries especially have very positive views about climate and economic impacts of stump energy use in the interviews but make negative arguments about the same issues in the media. This can have many explanations. For example, the stakeholders can discuss more freely and comprehensively in confidential interviews than in the media. Also, the selection of arguments chosen for news item s is strongly influenced by news criteria and journalistic norms and practices [35,71]. In addition, the media reports the views of energy and forest industries through interviews of representatives of large corporations, while in our interviews these stakeholders were represented by advocacy organisations. It is possible that individual companies are more agile to change their positions as a response to new research results and market changes than their advocacy organisations, and they might have been sensitised to the reservations and criticism that stump use has received $[25,29]$. And more broadly, corporations are known to have slightly different sets of constituents than their advocacy organisations [72].

The differences in the emphasis put on distinct environmental impacts that stump use might generate are apparent, particularly between the critical arguments of environmental NGOs and researchers and the less critical views of forest industries, government officials and advisory organisations. This echoe s the earlier Finnish forest policy debate characterized by strong polarisation between conservation and use $[67,70]$. In line with our findings, a similar polarisation has also been observed in bioenergy, bioeconomyand different silviculture regime debates $[43,44]$. Whether media plays a role in strengthening this divide is uncertain, but at least the finding of a little nuance filtering to media reporting shows that a simplified polarisation can easily be portrayed and perhaps maintained by the media.

In essence, the debate over tree stump use reflects two partially conflicting goals of current environmental policies. One focuses on promoting bioenergy relying on increasing use and extraction of biomass, while the other advances the circular economy, resource efficiency and recycling $[73,74]$. In our interviews, however, we find only modest differences in the argumentation of the most likely proponents of these positions, and possible competitors of stumps as a resource - the energy and forest industries. The similarity of views between the two industries is likely a result of stumps differing from many other biomass sources. Other uses for stumps than energy production are very limited. Indeed, our analysis shows that neither energy nor forest industries view the competition impacts of stump use negatively.

The fact that bioenergy sustainability policy is placed under climate policy in the EU [59] might steer the bioenergy sustainability discussion to focus on climate impacts. Journalists may also simply find it convenient to treat the environmental impacts of stumps under the general frame of climate change, since climate issues have dominated Finnish environmental news coverage during the past two decades [75]. Additionally, energy and climate debates are closely connected. About $10 \%$ of climate news by the Helsingin Sanomat have focused on energy issues [37]. Climate impacts have also been assessed by several recent studies of forest bioenergy, while less attention has been paid to other impacts $[14,15,17]$. Fina lly, the polarised nature of the debate over the climate impacts of stump utilisation - dividing also the researcher community into two camps - might make it an especially newsworthy topic for the media. Since climate impacts are the subject of the most polarised debate, a systematic meta-study of the climate impacts of stump energy use would be beneficial to increase the transparency of the discussion. However, 
because of the complexity of the issue and various vested interests involved, more comprehensive res earch focusing on socio-economic and cultural underpinnings is required as well.

Stakeholders across the board criticise the impacts of stump extraction on the landscape, recreation and the environment, beyond climate change impacts. However, our analysis shows that the media discussion on the impacts of stump utilisation on landscape and recreational use is very scarce in Finland. This is somewhat surprising since stump use represents a relatively novel and widespread land use type with rather dramatic and unpopular impacts on the landscape [25].

Although we identify a tension between environmental ecosystem sustainability concerns and economic forest-dependent business orientation, less polarised arguments bringing up general sustainability concerns can also be identified. The government officials elaborate their arguments in a way that falls between the extremes of the negative environmental NGO and positive forest industry arguments. This observation echoes the findings on other sustainability discussions in recent forest policy formulation in Finland [43]. This can signal that they have an intermediary role among the stakeholders.

Our analysis shows that the stakeholders' views on economic impacts are somewhat aligned, but the economic arguments vary in terms of where and by whom they would be experienced. The most common economic arguments for stump utilisation found in our analysis appeal to local impacts, which is in line with the findings of Rahman et al. [39] on public perception of stump removals in Finland. The economic arguments we find against stump use most commonly refer to technological problems related to stumps as a fuel. However, in the future it might be possible to decrease the costs related to the stump supply chain with new technologies [11].

Our analysis addresses a country with large forest resources and a small population as well as an economically and ecologically significant forest sector [53]. As forest use is a key issue in the sustainability debate, the analysis of arguments portrayed in the media and among expert stakeholders is policy-relevant and topical. However, the special characteristics of Finnish forestry can also pose some limitations on the broader generalizability of the identified arguments and stakeholder-argument connections, calling for cross-national comparative studies.

\section{Conclusions}

Our case represents a debate where uncertainty of knowledge and decision stakes are high, the source of relevant knowledge is contested, and the value base of arguments and decisions are not transparent. Our analysis shows that the stakeholders position themselves differently, and the basis of their argumentation is not always clear. The division between forest use and conservation prevails across Europe, where stakeholders generally perceive forest bioenergy goals as conflicting with biodiversity conservation and in alignment with economic and employment goals. Even with the new forest-based biomass sourcestumps - the stakeholders position themselves quite similarly with these deeply rooted views of forest utilisation. However, the views of energy and forest industries - traditional competitors over forest-based resources - seem to be in alignment when it comes to stump energy use.

The debate over the sustainability of tree stump use shows that science-based knowledge claims can have high visibility in media representations, yet a rather limited focus compared to the issues that experts are prepared to consider. Our analysis shows that stakeholders consider a broad range of impacts when interviewed, while their views are portrayed as sharper and more polarised in the media. The strong polarisation in media regarding the climate change impacts of stump energy use can stem not only from journalistic decisions and the differing interests of the stakeholder groups, but also from the research analysing the topic from different perspectives and with different methodological settings.

Stump energy use is subsidized in Finland, and politically it is a part of the renewable energy portfolio, where the EU targets require a considerable and rapid increase. However, during the last years, energy use of stumps has decreased. The decrease can result from multiple factors, among which the public discussion on climate impacts and other sustainability issues can be an important one. In otherwords, the media discussion can have the opposite impact on bioenergy utilisation than the policy targets. In any case, our analysis shows that media discussion highlights only some aspects of natural resource use options and impacts, while a wider set of impacts is considered by experts. At the same time, we observe that research findings generate considerable public discussion and concern in Finland. In circumstances where opinions 
on sustainability are divided, transparency of different viewpoints is essential for supporting the sustainability as well as legitimacy of forest bioenergy. Additionally, the fact that the environmental, social and economic impacts of tree stump harvesting emerge at different temporal and spatial scales with variable time lags between actions and impacts merits attention. However, our study suggests that media debate in particular is ill-equipped to tackle such variability.

In addition to following public discussion and reporting on the recent scientific findings, policymakers and implementers should engage in more versatile utilisation of knowledge brokerage. The availability of reliable scientific results is a precondition for efficient societal use of science -based knowledge but the channels through which the knowledge filters to decision-making can be even more crucial. In the case of stump energy use this is especially challenging due to the partly incompatible or even conflicting research findings, which different stakeholder groups can utilise to their advantage. Thus, when deciding on their bioenergy positions relative to the bioeconomy, the circular economy and climate policy, policymakers should not only meet with a diverse set of stakeholders, but also consider the different sustainability dimensions explicitly, to create a holistic view.

\section{Acknowledgements}

The research leading to these results has received funding from the Eu ropean Commission's Seventh Framework Programme (OpenNESS project, grant agreement no. 308428) and from the Academy of Finland (FutWend project, grant agreement no. 297742). The authors would like to thank Anna Repo for her contribution to the database used in the study and the valuable input of the interviewees.

\section{References}

[1] P. Upham, et al., The sustainability of forestry biomass supply for EU bioenergy: a post-normal approach to environmental risk and uncertainty, Environ. Sci. Pol. 14 (5) (2011) 510-518.

[2] C. Söderberg, K. Eckerberg, Rising policy conflicts in Europe over bioenergy and forestry, For. Pol. Econ. 33 (2013) 112-119.

[3] G. Bostedt, M. Mustonen, P. Gong, Increasing forest biomass supply in northern Europe - countrywide estimates and economic perspectives, Scand. J. For. Res. 31 (3) (2016) 314-322.

[4] EEA, reportRenewable Energy in Europe 2016: Recent Growth and Knock-on Effects. EEA Report No 4/2016. 2016, Copenhagen: European Environment Agency.

[5] A. Kilpeläinen, et al., Net climate impacts of forest biomass production and utilization in managed boreal forests, GCB Bioenergy 8 (2) (2016) 307-316.

[6] P. Torssonen, et al., Effects of climate change and management on net climate impacts of production and utilization of energy biomass in Norway spruce with stable age-class distribution, GCB Bioenergy 8 (2) (2016) 419-427.

[7] P. Upham, L. Dendler, Scientists as policy actors: a study of the language of biofuel research, Environ. Sci. Pol. 47 (2015) 137-147.

[8] J.S. Kotiaho, M. Ollikainen, J. Seppälä, Sustainability crisis brews in EU forestry, Nature 551 (2017) 33.

[9] J. Palmer, S. Owens, Indirect land-use change and biofuels: the contribution of assemblage theory to place-specific environmental governance, Environ. Sci. Pol. 53 (2015) 18-26.

[10] P. Pelkonen, et al. (Ed.), Forest bioenergy for Europe. What Science Can Tell Us, vol. 4, European Forest Institute, Joensuu, 2014.

[11] S.M. Berch, et al., Criteria and guidance considerations for sustainable tree stump harvesting in British Columbia, Scand. J. For. Res. 27 (8) (2012) 709-723.

[12] UNECE, European Forest Sector Outlook Study II, United Nations Economic Commission for Europe \& Food and Agriculture Organization of the United Nations, 2011.

[13] O. Díaz-Yáñez, et al., Forest chips for energy in Europe: current procurement methods and potentials, Renew. Sustain. Energy Rev. 21 (2013) 562-571.

[14] P. Edwards, J. Lacey, Can't climb the trees anymore: social licence to operate, bioenergy and whole stump removal in Sweden, Soc. Epistemol. 28 (3-4) (2014) 239-257.

[15] M. Forsius, et al., Modelling impacts of forest bioenergy use on ecosystem sustainability: lammi LTER region, southern Finland, Ecol. Indicat. 65 (2016) 66-75. 
[16] E.-L. Lindholm, S. Berg, P.-A. Hansson, Energy efficiency and the environmental impact of harvesting stumps and logging residues, Eur. J. For. Res. 129 (6) (2010) 1223-1235.

[17] H. Saarikoski, et al., Exploring operational ecosystem service definitions: the case of boreal forests, Ecosys. Serv. 14 (2015) 144-157.

[18] T. Snäll, et al., Transient trade-off between climate benefit and biodiversity loss of harvesting stumps for bioenergy, GCB Bioenergy 9 (12) (2017) 1751-1763.

[19] H.-S. Helmisaari, L. Kaarakka, Nutrient management for sustainable production of energy biomass in boreal forests, in:S. Kellomäki, A. Kilpeläinen, A. Alam (Eds.), Forest BioEnergy Production: Management, Carbon Sequestration and Adaptation, Springer New York, New York, NY, 2013, pp. 81-94.

[20] M. Palviainen, et al., Nitrogen, phosphorus, carbon, and suspended solids loads from forest clearcutting and site preparation: long-term paired catchment studies from Eastern Finland, Ambio 43 (2) (2014) 218-233.

[21] R. Hyvönen, et al., Effects of stump harvesting on soil C and N stocks and vegetation 8-13years after clear-cutting, For. Ecol. Manag. 371 (2016) 23-32.

[22] T. Toivanen, et al., The effect of forest fuel harvesting on the fungal diversity of clear-cuts, Biomass Bioenergy 39 (2012) 84-93.

[23] K. Juutilainen, et al., The effects of forest management on wood-inhabiting fungi occupying dead wood of different diameter fractions, For. Ecol. Manag. 313 (2014) 283-291.

[24] G. Egnell, Effects of slash and stump harvesting after final felling on stand and site productivity in Scots pine and Norway spruce, For. Ecol. Manag. 371 (2016) 42-49.

[25] V. Gundersen, et al., Effects of bioenergy extraction on visual preferences in boreal forests: a review of surveys from Finland, Sweden and Norway, Scand. J. For. Res. 31 (3) (2016) 323-334.

[26] M. Makkonen, et al., Policy coherence in climate change mitigation: an ecosystem service approach to forests as carbon sinks and bioenergy sources, For. Pol. Econ. 50 (2015) 153-162.

[27] A. Felton, et al., How climate change adaptation and mitigation strategies can threaten or enhance the biodiversity of production forests: insights from Sweden, Biol. Conserv. 194 (2016) 11-20.

[28] L. Sokka, et al., Environmental impacts of the national renewable energy targets - a case study from Finland, Renew. Sustain. Energy Rev. 59 (2016) 1599-1610.

[29] M. Troldborg, S. Heslop, R.L. Hough, Assessing the sustainability of renewable energy technologies using multi-criteria analysis: suitability of approach for national-scale assessments and associated uncertainties, Renew. Sustain. Energy Rev. 39 (2014) 1173-1184.

[30] T. Walker, et al., Biomass Sustainability and Carbon Policy Study, Manomet Centre for Conservation Sciences, Brunswick, ME, 2010, p. 182.

[31] G. Zanchi, N. Pena, N. Bird, Is woody bioenergy carbon neutral? A comparative assessment of emissions from consumption of woody bioenergy and fossil fuel, GCB Bioenergy 4 (6) (2012) 761-772.

[32] A. Repo, et al., Forest bioenergy climate impact can be improved by allocating forest residue removal, GCB Bioenergy 4 (2) (2012) 202-212.

[33] Y. Melin, H. Petersson, T. Nordfjell, Decomposition of stump and root systems of Norway spruce in Sweden-a modelling approach, For. Ecol. Manag. 257 (5) (2009) 1445-1451.

[34] G.M. Domke, et al., Carbon emissions associated with the procurement and utilization of forest harvest residues for energy, northern Minnesota, USA, Biomass Bioenergy 36(2012) 141-150.

[35] C. Morris, 'Taking the Politics Out of Broccoli': Debating (De)meatification in UK National and Regional Newspaper Coverage of the Meat Free Mondays Campaign, Sociologia Ruralis 58 (2) (2018) 433-452.

[36] T. Metze, Fracking the debate: frame shifts and boundary work in Dutch decision making on shale gas, J. Environ. Pol. Plann. 19 (1) (2017) 35-52.

[37] J. Lyytimäki, Mainstreaming climate policy: the role of media coverage in Finland, Mitig. Adapt.

Strategies Glob. Change 16 (6) (2011) 649-661.

[38] M. Ekayani, D.R. Nurrochmat, D. Darusman, The role of scientists in forest fire media discourse and its potential influence for policy-agenda setting in Indonesia, For. Pol. Econ. 68 (2016) 22-29.

[39] A. Rahman, T. Khanam, P. Pelkonen, People's knowledge, perceptions, and attitudes towards stump harvesting for bioenergy production in Finland, Renew. Sustain. Energy Rev. 70 (2017) 107-116.

[40] D.M. Peters, et al., Energy wood from forests - stakeholder perceptions in five European countries, Energy, Sustain Soc 5 (1) (2015) 17.

[41] K.B. Lindahl, E. Westholm, Future forests: perceptions and strategies of key actors, Scand. J. For. Res. 27 (2012) 154-163. 
[42] A. Buijs, A. Lawrence, Emotional conflicts in rational forestry: towards a research agenda for understanding emotions in environmental conflicts, For. Pol. Econ. 33 (2013) 104-111.

[43] T. Harrinkari, P. Katila, H. Karppinen, Stakeholder coalitions in forest politics: revision of Finnish Forest Act, For. Pol. Econ. 67 (2016) 30-37.

[44] S. Huttunen, Stakeholder frames in the making of forest bioenergy legislation in Finland, Geoforum 53 (2014) 63-73.

[45] FAO, Global Forest Resources Assessment 2015: How Are the World's Forests Changing? Food and Agriculture Organization of the United Nations, Rome, 2016.

[46] Finland NREAP, Finland's National Action Plan for Promoting Energy from Renewable Sources Pursuant to Directive 2009/28/EC, (2010).

[47] M. Pekkarinen, Kohti Vähäpäästöistä Suomea. Uusiutuvan Energian Velvoitepaketti. [Towards Lowemission Finland], (2010).

[48] P.M.s.O. Finland, Action Plan for the Implementation of the Key Project and Reforms Defined in the Strategic Government Programme, Government Publications, 2016.

[49] Sitra, Leading the Cycle - Finnish Road Map to a Circular Economy 2016-2025, Sitra Studies, 2016.

[50] J. Lintunen, H.-L. Kangas, The case of co-firing: the market level effects of subsidizing biomass cocombustion, Energy Econ. 32 (3) (2010) 694-701.

[51] P. Kivimaa, P. Mickwitz, Public policy as a part of transforming energy systems: framing bioenergy in Finnish energy policy, J. Clean. Prod. 19 (16) (2011) 1812-1821.

[52] Natural Resources Institute Finland, Solid wood Fuel Consumption in Heating and Power Plants by Region 2000-2014, Statistics database, 2016.

[53] Finnish Forest Research Institute, Finnish Statistical Yearbook of Forestry, (2014).

[54] O. Äijälä, et al. (Ed.), Metsänhoidon Suositukset [Forestry Guidelines]. Metsätalouden kehittämiskeskus Tapion julkaisuja, Tapio, Helsinki, 2014.

[55] P.E.F.C. Finland, PEFC-metsäsertifioinnin Kriteerit, (2014) [Criteria for PECF certification].

[56] FSC Finland, Suomen FSC-standardi, (2011) [Finnish FSC-standard].

[57] S. Berg, Technology and Systems for Stump Harvesting with Low Ground Disturbance, Doctoral Thesis

Swedish University of Agricultural Sciences, Umeå, 2014.

[58] U.R. Fritsche, et al., Extending the EU Renewable Energy Directive sustainability criteria to solid bioenergy from forests, Nat. Resour. Forum 38 (2) (2014) 129-140.

[59] EC, Sustainability of Biomass Production, Commission of the European Communities, Brussels, 2016.

[60] Forestry Commission, Stump Harvesting: Interim Guidance on Site Selection and Good Practice, Forestry Commission, Edinburgh, 2009.

[61] A. Koistinen, J.-P. Luiro, K. Vanhatalo (Eds.), Metsänhoidon Suositukset Energiapuun Korjuuseen, Tapion julkaisuja, 2016[Guidelines for energy wood harvesting].

[62] Swedish Forest Agency, Swedish statistical Yearbook of Forestry 2011. 2011, Official Statistics of Sweden. Jönköping: Swedish Forest Agency.

[63] EC, A Sustainable Bioenergy Policy for the Period after 2020, Commission of the European Communities, Brussels, 2016.

[64] D. Silverman, Interpreting Qualitative Data: Methods for Analysing Talk, Text and Interaction, Sage, London, 2001.

[65] A. Bryman, Social Research Methods, Oxford university press, Oxford, 2015.

[66] A. Smith, A.o.U. Stirling, The politics of social-ecological resilience and sustainable socio-technical transitions, Ecol. Soc. 15 (1) (2010) 11.

[67] E. Hellström, Conflict Cultures - Qualitative Comparative Analysis of Environmental Conflicts in Forestry. Silva Fennica Monographs vol. 2, The Finnish Society of Forest Science, the Finnish Forest Research Institute, 2001.

[68] W.L. Benoit, R.L. Holbert, Empirical intersections in communication research: replication, multiple quantitative methods, and bridging the quantitative-qualitative divide, J. Commun. 58 (4) (2008) 615-628.

[69] K. Krippendorff, Content Analysis: an Introduction to its Methodology, SAGE, Thousand Oaks, CA, 2013.

[70] T. Rantala, E. Primmer, Value positions based on forest policy stakeholders' rhetoric in Finland,

Environ. Sci. Pol. 6 (3) (2003) 205-216.

[71] T. Harcup, D. O'Neill, What is news? Galtung and ruge revisited, Journal. Stud. 2 (2) (2001) 261-280.

[72] B. Cashore, I. Vertinsky, Policy networks and firm behaviours: govern ance systems and firm responses to external demands for sustainable forest management, Pol. Sci. 33 (1) (2000) 1-30. 
[73] D. D'Amato, et al., Green, circular, bio economy: a comparative analysis of sustainability avenues, J. Clean. Prod. 168 (2017) 716-734.

[74] D. Lazarevic, H. Valve, Narrating expectations for the circular economy: towards a common and contested European transition, Energy. Res. Soc. Sci. 31 (2017) 60-69.

[75] J. Lyytimäki, Prospects for environmental communication based on 25 Years of newspaper coverage of climate change and eutrophication in Finland, Appl. Environ. Educ. Commun. Int. J. 14 (4) (2015) 246-255 